\title{
Growth and Evaluation of Phenolic Compounds in Physalis angulata L. at Two Different Periods in the Bahia Reconcavo, Brazil
}

\author{
Claudia Brito de Abreu ${ }^{1}$, Manuela Oliveira de Souza ${ }^{1}$, Fabricio Mendes Miranda ${ }^{1}$, \\ Torben Grael dos Santos Rodrigues ${ }^{1} \&$ Fabio de Souza Dias ${ }^{1}$ \\ ${ }^{1}$ Universidade Federal do Recôncavo da Bahia, Campus Universitário de Cruz das Almas, Bahia, Brazil \\ Correspondence: Claudia Brito de Abreu, Universidade Federal do Recôncavo da Bahia, Campus Universitário \\ de Cruz das Almas, CEP: 44380-000, Cruz das Almas, Bahia, Brazil. Tel: 55-75-988-189-155. E-mail: \\ claudia01abreu@yahoo.com.br
}

$\begin{array}{lc}\text { Received: July 15, } 2017 & \text { Accepted: August 16, } 2017 \quad \text { Online Published: September 15, } 2017 \\ \text { doi:10.5539/jas.v9n10p145 } & \text { URL: https://doi.org/10.5539/jas.v9n10p145 }\end{array}$

The research is financed by CAPES (Coordenação de Aperfeiçoamento de Pessoal de Nivel Superior).

\begin{abstract}
Physalis angulata L. has aroused the interest of the researchers, since its properties come from the great therapeutic potential attributed to the commonly called substances of physalins. However, its cultivation in the study region lacks important information on the species adaptation to local soil and climate characteristics. The aim of this study was to evaluate the growth and concentration of phenolic compounds in P. angulata L. at two different periods in the Bahia Reconcavo. The experimental design was completely randomized blocks with 10 replicates. We evaluated the stem height and diameter, number of leaves and fruits, dry mass of leaves, stems and roots, leaf area, specific leaf area, leaf area ratio, leaf mass ratio and total phenolics, total flavonoids and antioxidant activity in the different organs of the plant. The growth was favorable from April to June. However, the concentration of phenolic compounds was higher in the period from December to February. The cultivation period influenced the growth and concentration of phenolic compounds in $P$. angulata L. in the Bahia Reconcavo.
\end{abstract}

Keywords: Camapu, DPPH, dry mass, total flavonoids, total phenols

\section{Introduction}

The Physalis production in Brazil is concentrated in the South, however, other species of the genus, such as Physalis angulata L., have been studied in the Northeast region, especially in the semi-arid region, mainly due to its medicinal potential, seeds conservation and differential expression of genes in seeds and seedlings submitted to abiotic stress (M. Souza, C. Souza, Barroso, \& Pelacani, 2014; Souza, 2015; Souza et al., 2016). The species occurs in almost all country (Stehmann et al., 2015), but in Bahia there are records in the municipalities of Seabra, Água Quente, Mucugê and Rio de Contas (Matos, 2000).

The interest in the species comes from the great therapeutic potential attributed to the substances commonly known as physalins (Tomassini, 2000) and its proven anti-inflammatory, immunotherapy, leishmanicidal action with potential in vitro and in vivo by inhibiting cutaneous leishmaniasis and induction of cell death by apoptosis of human oral cancer cells (Bastos, Silveira, Salgado, Picanço-Diniz, \& Nascimento, 2008; Guimarães et al., 2009; Lee et al., 2009).

In addition to the physalins, (Tomassini, 2000), the phenolic compounds can also be found in the Physalis genus, because, according to Ismail and Alam (2001), P. angulata contains simple and glycosides flavonoids. According to Kusumaningtyas, Laily, and Limandha (2015), total phenols were found in P. angulata, attributing the species potential for use as functional food.

In plants, phenolic compounds play an important role in growth, reproduction and protection, acting against pathogens, predators and environmental stress, besides contributing to the organoleptic characteristics of fruits and vegetables (Balasundram, Sundram, \& Samman, 2006). For human, the phenolic compounds show promising results as powerful antioxidants, which protect the human body from free radicals whose formation is associated with normal aerobic cell metabolism (Carvalho, Mattietto, Rios, \& Moresco, 2014). 
The Physalis cultivation may be an alternative for the small and medium rural producers, since the obtaining of these substances that have therapeutic properties (Yu et al., 2010; Sun et al., 2011) is linked to extractive practices that generates the reduction or even the risk of extinction of the species. According to Betemps, Fachinello, Lima, Galarça, and Rufato (2014), the study of Physalis sowing time is necessary, since they provide important information about the adaptation to the local soil and climate characteristics, allowing the appropriate management of the species. Until now, data reporting the best planting period for the growth and production of phenolic compounds in $P$. angulata L. have not been found.

Thus, the aim of this study was to evaluate the growth and production of phenolic compounds in P. angulata $\mathrm{L}$. in two different periods in the Bahia Reconcavo, Brazil.

\section{Material and Methods}

\subsection{Localization and Conditions of Plant Growth}

The seeds of $P$. angulata $\mathrm{L}$. were obtained from fruits, from plants grown in a greenhouse at the Forest Garden Experimental Unit of the State University of Feira de Santana, Bahia. However, the experiment was conducted at the experimental station of the Bahia Reconcavo Federal University, located in the municipality of Cruz das Almas, BA, $\left(12^{\circ} 40^{\prime} 19^{\prime \prime} \mathrm{S}\right.$ and $39^{\circ} 06^{\prime} 22^{\prime \prime} \mathrm{W}, 220 \mathrm{~m}$ of altitude).

The local climate is hot and humid tropical with a dry season in the summer, As type, according to the classification of Köppen. The region has an average annual rainfall of 1,224 $\mathrm{mm}$, average annual temperature of $22.4^{\circ} \mathrm{C}$ and $80 \%$ of relative humidity (Almeida, 1991).

The soil of the experimental area was classified as Dystrophic Cohesive Yellow Latosol (Empresa Brasileira de Pesquisa Agropecuária [EMBRAPA], 2013) and presented the following physical and chemical characteristics, for the layers $0-20 \mathrm{~cm}$ and $20-40 \mathrm{~cm}$, respectively: sand $=828$ and $791 \mathrm{~g} \mathrm{Kg}^{-1}$; silt $=72$ and $69 \mathrm{~g} \mathrm{Kg}^{-1}$; clay $=100$ and $140 \mathrm{~g} \mathrm{Kg}^{-1} ; \mathrm{pH}\left(\mathrm{H}_{2} \mathrm{O}\right)=5.6$ and $5.0 ; \mathrm{P}=2.00$ and $1.00\left(\mathrm{mg} / \mathrm{dm}^{3}\right) ; \mathrm{K}=0.09$ and $0.05\left(\mathrm{mg} / \mathrm{dm}^{3}\right) ; \mathrm{Ca}^{2+}=0.47$ and $0.44\left(\mathrm{cmol}(\mathrm{c}) / \mathrm{dm}^{3}\right) ; \mathrm{Mg}^{2+}=0.35$ and $0.24\left(\mathrm{cmol}(\mathrm{c}) / \mathrm{dm}^{3}\right) ; \mathrm{Al}^{3+}=0.0$ and $0.3\left(\mathrm{cmol}(\mathrm{c}) / \mathrm{dm}^{3}\right) ; \mathrm{H}+\mathrm{Al}=2.09$ and $2.53\left(\mathrm{cmol}(\mathrm{c}) / \mathrm{dm}^{3}\right) ; \mathrm{TB}=0.94$ and $0.76\left(\mathrm{cmol}(\mathrm{c}) \mathrm{dm}^{3}\right) ; \mathrm{CEC}=3.03$ and $3.29\left(\mathrm{cmol}(\mathrm{c}) / \mathrm{dm}^{3}\right) ; \mathrm{OM}(\%)=15.0$ and $10.0 ; \mathrm{V}(\%)=31$ and $23 \%$, respectively. Before the implementation of the experiment, the soil was corrected with dolomitic limestone.

The sowing in the greenhouse and the transplanting to the field were carried out in two different periods, in March and November of 2016. The transplants to the field were carried out in April and December 2016. The first and second evaluations were carried out from April to June 2016 and from December 2016 to February 2017 , respectively.

The seeds were sown in plastic tubes with a capacity of $327 \mathrm{~g}$ containing soil, sand and organic compound in the proportion (2:1:1), irrigated daily and kept in a greenhouse until the day of transplanting. Upon reaching an average size of $20 \mathrm{~cm}$, the seedlings were transferred to the experimental field in pits with width, length and depth of $40 \times 40 \times 40 \mathrm{~cm}$, respectively. In spacing of $2 \mathrm{~m} \times 1 \mathrm{~m}$. The experimental design was completely randomized blocks with 10 replicates.

\subsection{Evaluation of Plant Growth}

The following growth characteristics were evaluated weekly in 8 plants of each block: height of the main branch, diameter of the stem, number of leaves and fruits. The height was measured with millimeter ruler from the neck to the apex of the plant (terminal bud); the diameter of the stem was measured using a digital caliper $(\mathrm{cm})$ from the neck of the plant and the number of leaves and fruits were done by manual counting.

After 60 days of cultivation, the plants were collected and separated in leaves, stems and roots, placed in properly identified paper bags and taken to drying in a greenhouse with forced air circulation at $40 \pm 5{ }^{\circ} \mathrm{C}$, until constant mass, to determine the dry masses of leaves (DML), stem (DMS) and roots (DMR). A precision analytical balance of $10^{-4} \mathrm{~g}$ was used. For the collection of the roots in the field, a $2 \mathrm{~mm}$ mesh screen was used to separate the soil from the roots.

The leaf area per plant was determined by the ratio of the dry mass of ten leaf discs and the total dry mass of the leaves. The leaf discs were obtained with the aid of a metal perforator of known area, avoiding the central vein as described in Benincasa (2004). The foliar area ratio (FAR), foliar mass ratio (FMR) and specific leaf area (SLA) were determined from total leaf area (TLA), expressed in $\mathrm{cm}^{2}$, of the plant dry mass (PDM) and leaves dry mass (LDM), expressed according to Benincasa (2004). 


\subsection{Total Flavonoid, Phenolic and Antioxidant Activity}

The plant material was crushed for the analysis of total phenols, total flavonoids and antioxidant activity. The extractive solution of the leaves, stems and roots were obtained by extraction under reflux with hydroalcoholic solution (ethyl alcohol and water, 40\% v/v) for 30 minutes, developed and validated by Petry, Souza, Bassani, Petrovick and González-Ortega (1998).

\subsubsection{Total Flavonoids}

The determination of flavonoids followed the methodology proposed by Marques et al. (2012), of the extractive solution were transferred to $10 \mathrm{ml}$ volumetric flasks, in which $2.0 \mathrm{ml}$ of $\mathrm{AlCl}_{3}$ ethanolic solution $(5 \%$, m/v) were added. The volume was adjusted with the hydroalcoholic solution $(40 \%, \mathrm{v} / \mathrm{v})$. After addition of the $\mathrm{AlCl}_{3}$ solution $(5 \%, \mathrm{~m} / \mathrm{v})$ we waiting $30 \mathrm{~m}$ and the readings were carried out in a spectrophotometer (WPA Lightwave II, Biochrom, China) at $408 \mathrm{~nm}$. The tests were carried out in triplicate. The total flavonoid content was calculated from the calibration curve of quercetin used as standard and expressed in milligrams of quercetin equivalents per gram of dry extract $(\mathrm{mgQE} / \mathrm{gDE})$.

\subsubsection{Total Phenolics}

The total phenol contents of the extracts were determined using the Folin-Ciocalteau reagent and gallic acid as standard (Slinkard \& Singleton, 1977). The extract sample $(0.5 \mathrm{~mL})$ and $2 \mathrm{~mL}$ of sodium carbonate $\left(75 \mathrm{~g} \mathrm{~L}^{-1}\right)$ were added to $2.5 \mathrm{~mL}$ of $10 \%(\mathrm{v} / \mathrm{v})$ Folin-Ciocalteau reagent. After $30 \mathrm{~min}$ of reaction at room temperature and protected from light, the readings were carried out in a spectrophotometer (WPA Lightwave II, Biochrom, China) at $765 \mathrm{~nm}$. The tests were carried out in triplicate. The total phenolic compounds content was calculated from the calibration curve of gallic acid and expressed in milligrams of gallic acid equivalents per gram of dry extract (mgGAE/gDE).

\subsubsection{Antioxidant Capacity Determined by DPPH Radical Assay}

The determination of antioxidant activity by the capture of free radical DPPH (2,2 diphenyl-1-picrylhydrazyl) followed the methodology proposed by Rufino et al. (2007). From the extract obtained above, five different concentrations $\left(1.00,3.00,5.00,7.00,10.00 \mathrm{~g} \mathrm{~L}^{-1}\right)$ were prepared in triplicate in test tubes. In the dark environment, a $300 \mu \mathrm{L}$ aliquot of each test tube extract dilution was transferred with $3.9 \mathrm{~mL}$ of the DPPH radical and homogenized on a tube shaker. We was used $300 \mu \mathrm{L}$ of the control solution (methyl alcohol, acetone and water) with $3.9 \mathrm{~mL}$ of the DPPH radical and then homogenized the solution. The DPPH solution was prepared on the same day before the analysis and stored in volumetric flask covered within an aluminum paper protected from light until analysis. The methyl alcohol was used as the blank to calibrate the spectrophotometer. The whole procedure was done in triplicate, and the spectrophotometer (WPA Lightwave II, Biochrom, China) at readings at $517 \mathrm{~nm}$.

\subsection{Statistical Analysis}

The results were statistically analyzed, and the analysis of variance was carried out. The averages of the treatments were compared by the F test at 5\% probability. The Sisvar 4.6 software was used (Ferreira, 2011).

\section{Results and Discussion}

\subsection{Climatic Data during the Study Period}

The climatological data of the study period are shown in Figure 1, in which the monthly values of the rainfall and the monthly average of the temperature collected during the experiments are found in the municipality of Cruz das Almas in the Bahia Reconcavo, Brazil. The period considered the driest was January $(15 \mathrm{~mm})$ and the rainiest was May (145 $\mathrm{mm})$. 


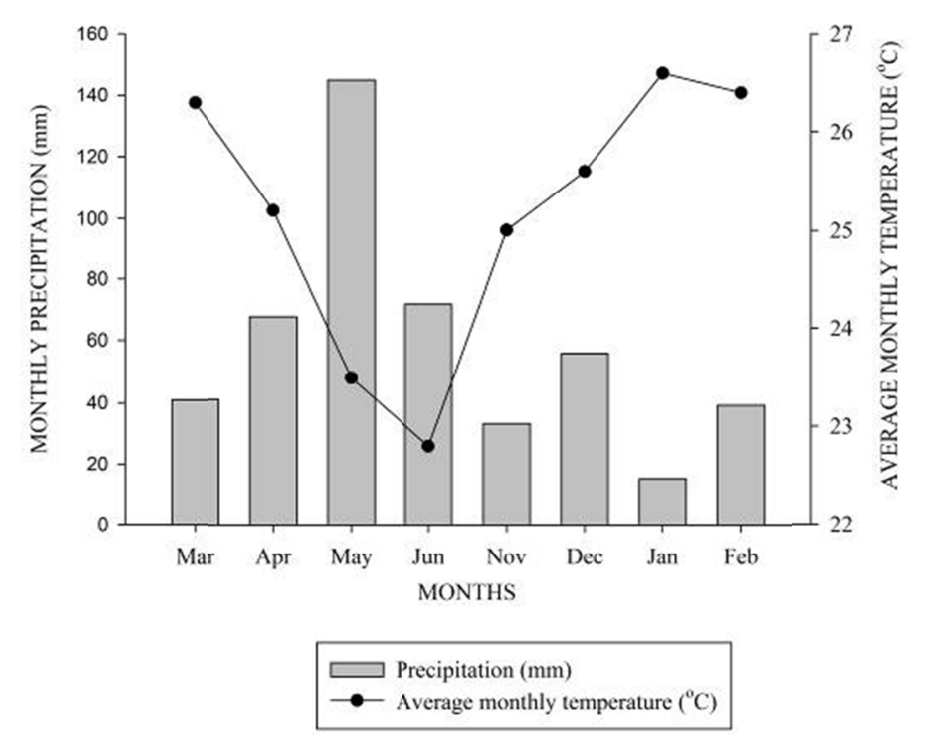

Figure 1. Monthly precipitation $(\mathrm{mm})$ and average monthly temperature $\left({ }^{\circ} \mathrm{C}\right)$ from March 2016 to February 2017 , in Cruz das Almas, BA. Source: National Institute of Meteorology INMET/Brazil, 2017

It is still possible to observe in Figure 1 that the month of January presented the highest average temperature of the year, around $26.6^{\circ} \mathrm{C}$ while the lowest temperature occurred in June (average of $22.8{ }^{\circ} \mathrm{C}$ ). Thus, according to Figures 2 to 5, the climatic conditions of the municipality of Cruz das Almas, may influence the growth of $P$. angulata $\mathrm{L}$. grown in the field. Since the analysis of variance showed significant differences $(p<0.01)$ among the treatments, for all growth characteristics evaluated.

\subsection{Influence of Cultivation Period on Growth of Physalis angulata L.}

In Figure 2, the height $(\mathrm{cm})$, stem diameter $(\mathrm{cm})$, number of leaves and number of fruits of P. angulata L. were influenced by the growing period.
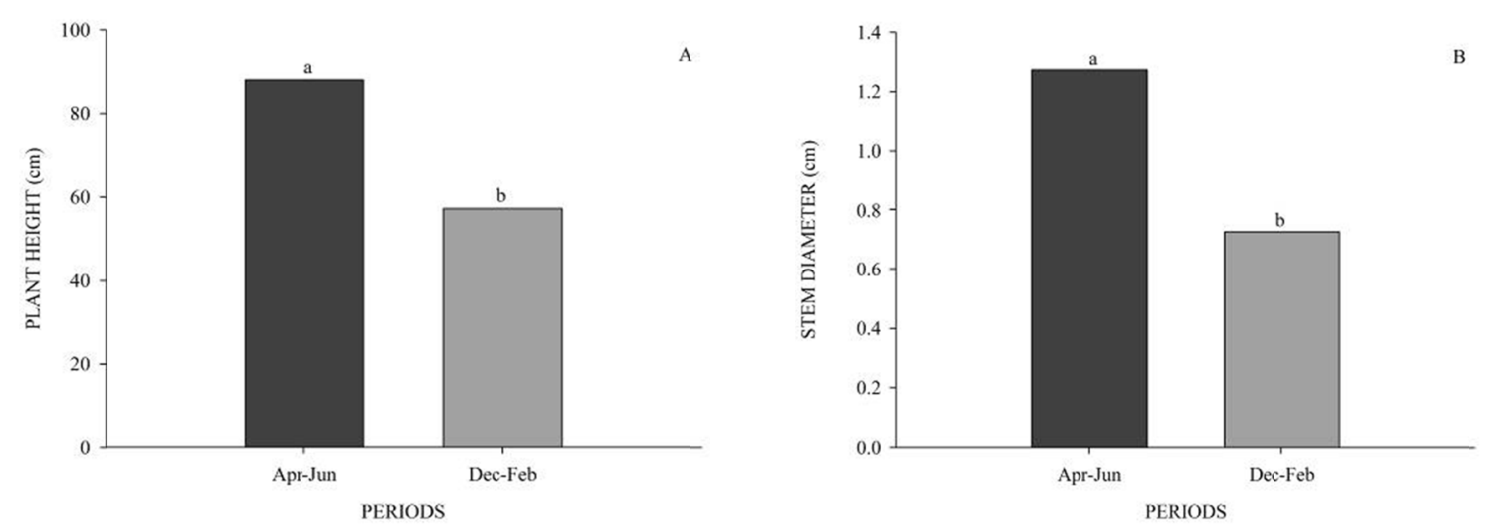

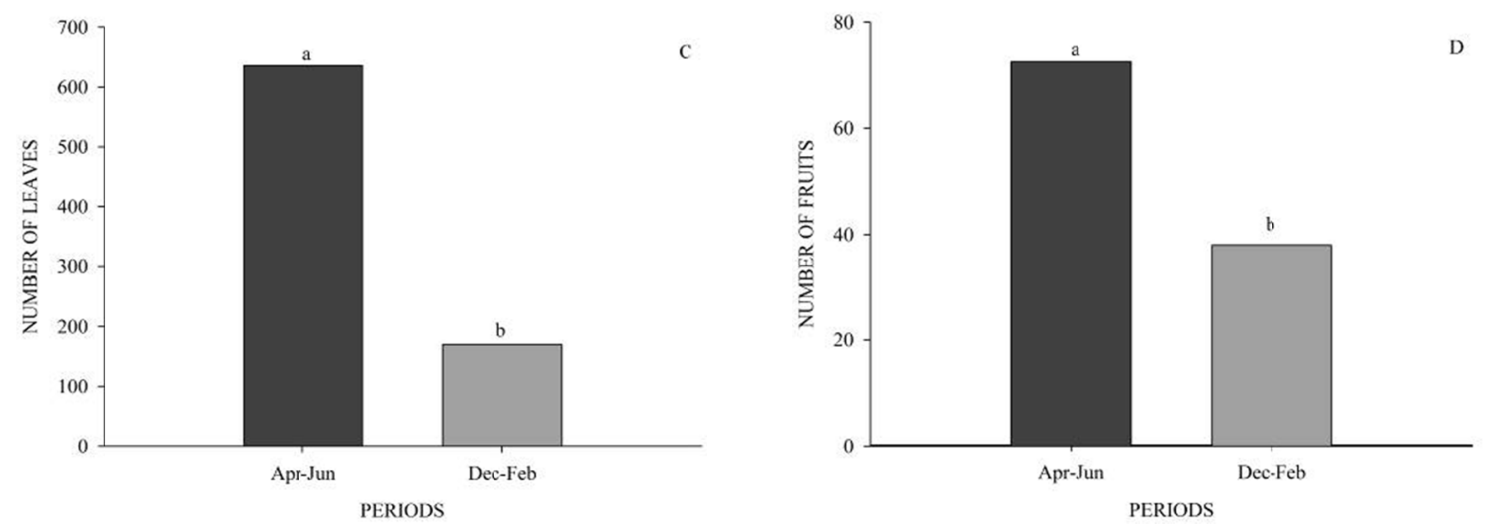

Figure 2. Height (cm) (A), stem diameter (cm) (B), number of leaves $(C)$ and number of fruits $(D)$ of Physalis angulata L., cultivated in the field in two different periods (April to June 2016) and (December 2016 to February 2017). Averages followed by distinct letters differ statistically from each other by the $F$ test at $5 \%$ of probability

The highest results were obtained between April and June for the variables height $88.05 \mathrm{~cm}$ (Figure 2A), stem diameter $1.27 \mathrm{~cm}$ (Figure 2B), number of leaves 636.32 (Figure 2C) and number of fruits 72.54 (Figure 2D). Thus, this period provided the Physalis plants with an increase in growth of $54.5 \%, 75.6 \%, 271.5 \%$ and $91.6 \%$, respectively, compared to the period of December 2016 to February 2017.

Considering the cultivation carried out in December to February, the number of leaves presented the largest reduction $(73.08 \%)$ in relation to the other variables analyzed (Figure $2 \mathrm{C}$ ).

A. Rufato, L. Rufato, Lima, and Muniz (2013) state that Physalis plants present better growth in temperatures between 8 and $20{ }^{\circ} \mathrm{C}$. Thus, it is possible that $P$. angulata L. plants are better adapted to the environmental conditions of the study area from April to June. Betemps, Fachinello, Lima, Galarça, and Rufato (2014), in a study on the growth of Physalis in function of three sowing times in the region of Pelotas-RS, observed that the sowing of Physalis carried out at the beginning of September (late winter) resulted in plants with higher vegetative growth and number of fruits. Lima, Gonçalves, Tomaz, Fachinello and A. Rufato (2010) state that the cultivation of Physalis in places with high temperatures around $30^{\circ} \mathrm{C}$ tend to favor vegetative growth. However, in this study the results diverge, which may further enhance the ability of these plants to adapt to different environments.

\subsection{Influence of Cultivation Period in Production Dry Mass of Physalis angulata L.}

Figure 3 shows that the values of dry mass production in all parts of $P$. angulata L. plants were higher in April to June in relation to the period of December to February. Thus, dry masses of leaves (DML) (Figure 3A), stem (DMS) (Figure 3B) and roots (DMR) (Figure 3C) showed increases of 336\%, 586.3\% and 95.6\%, respectively. The increase in plant height, stem diameter and number of leaves (Figures 2A, 2B, and 2C), provided increases in the accumulation of dry mass in Physalis plants (Figure 3).
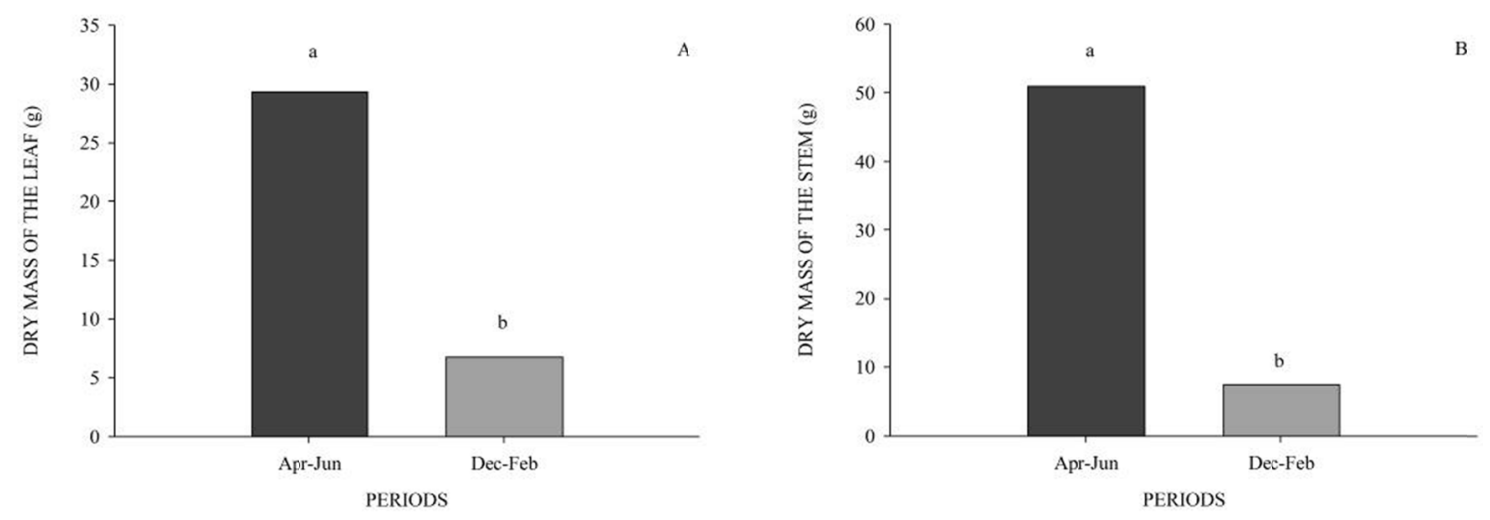

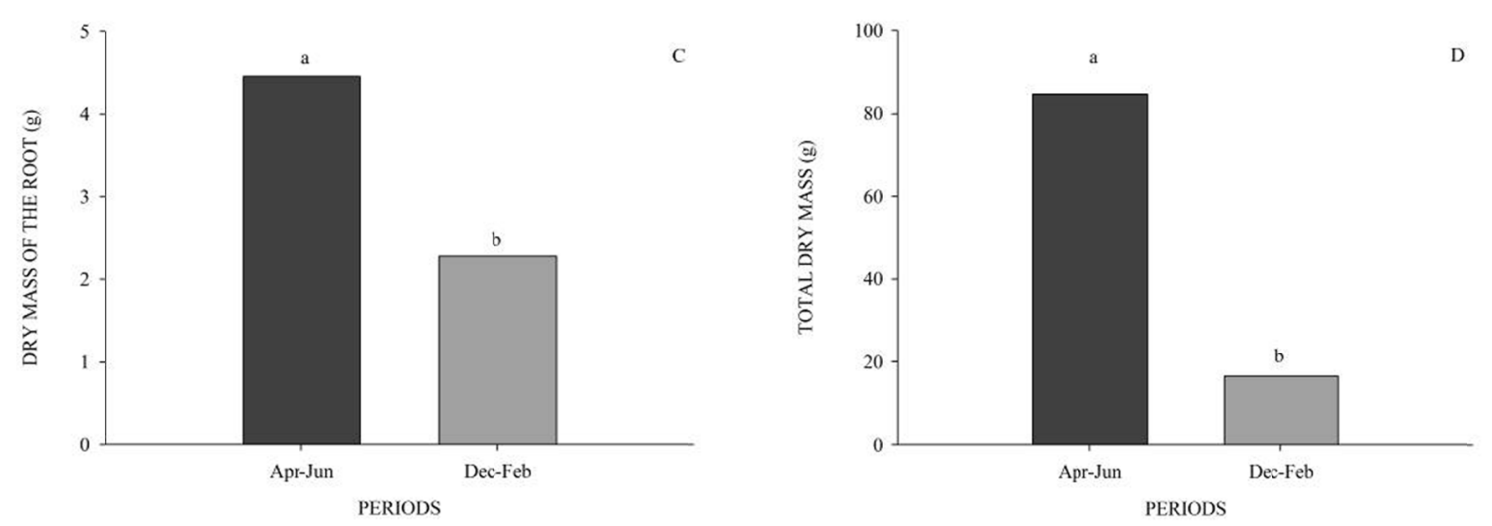

Figure 3. Dry mass of the leaf (g) (A), dry mass of the stem (g) (B), dry mass of the root (g) (C) and total dry mass (g) (D) of Physalis angulata L. plants cultivated in the field in two different periods (April to June 2016) and (December 2016 to February 2017). Averages followed by distinct letters differ statistically from one another by the $\mathrm{F}$ test at $5 \%$ probability

Considering that the cultivation from December to February reduced the dry mass of all parts of the plant, the total dry mass (TDM) decreased by $80.56 \%$ in this period, in relation to the cultivation from April to June (Figure 3D). The dry mass of the plants is directly associated with the capacity of atmospheric $\mathrm{CO}_{2}$ fixation by photosynthesis (Zuffo, Zuffo Júnior, L. Silva, R. Silva, \&Menezes, 2016) and it evaluates the growth of the plant, relating the amount of organic matter accumulated per unit of time (Martinazzo, Perboni, Posso, Aumonde, \& Bacarin, 2015). Probably the dry mass reduction of all parts of the plant in this period is due to the species being a $\mathrm{C}_{3}$ plant and presenting a photosynthetic capacity compromised at high temperatures, since it intensifies the respiration and photorespiration processes (Taiz \& Zeiger, 2013).

\subsection{Influence of Cultivation Period in Leaf Area and Specific Leaf Area of Physalis angulata L.}

According to Figure 4, the cultivation from April to June presented greater leaf area (LA) in relation to the period from December to February. Thus, increases of $276.7 \%$ in the LA of $P$. angulata plants, cultivated from April to June, were observed (Figure 4A). According to Reis, Azevedo, Albuquerque, and Silva Junior (2013), the increase of leaf area in plants favors greater interception of solar energy, favoring the accomplishment of photosynthesis, resulting in the greater production of photo-assimilated that can be used for growth.
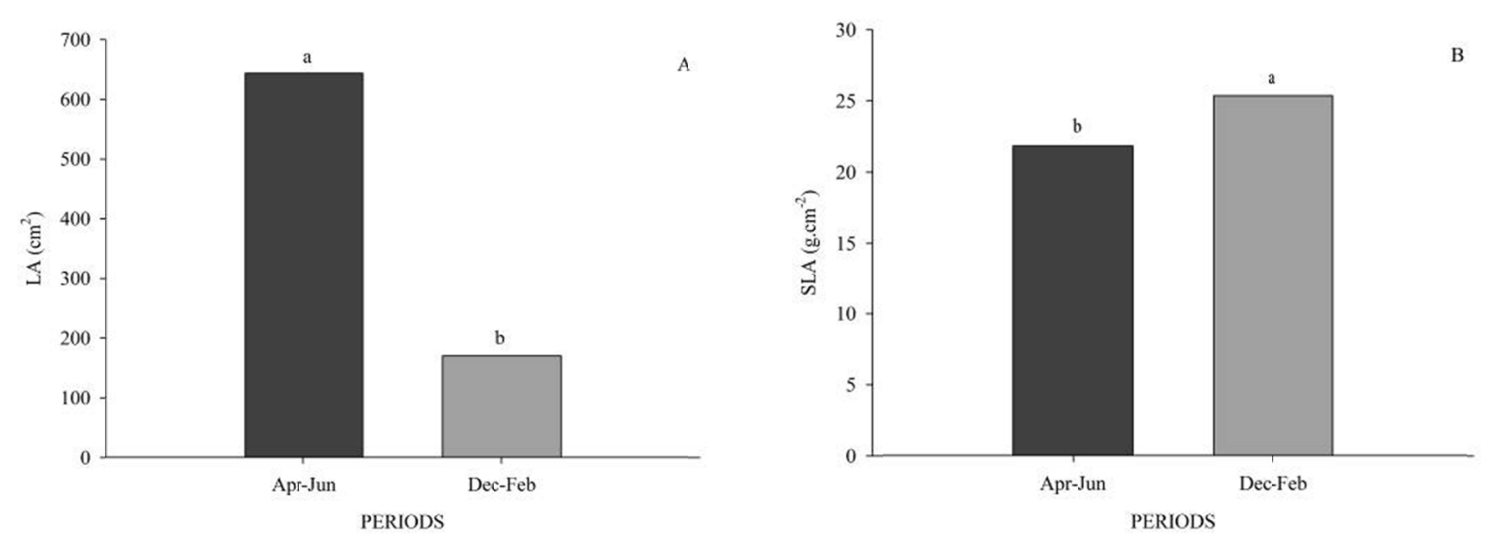

Figure 4. Leaf area-LA $\left(\mathrm{cm}^{2}\right)(\mathrm{A})$ and specific leaf area-SLA $\left(\mathrm{g} \mathrm{cm}^{-2}\right)(\mathrm{B})$ of Physalis angulata L. plants, cultivated in the field in two different periods (April to June 2016) and (December 2016 to February 2017).

Means followed by distinct letters differ statistically from one another by the F test at 5\% probability

The specific leaf area (SLA) in P. angulata plants increased from December to February (16.2\%) (Figure 4B). According to Taiz and Zeiger (2013), the SLA represents the differences in leaf thickness, and consequently, it 
can be inferred if the plants are accumulating photo-assimilated in their leaves or being transported to other parts.

\subsection{Influence of Cultivation Period in Leaf Area Ratio and Leaf Mass Ratio of Physalis angulata L.}

Figure 5 shows the values of leaf area ratio (LAR) (Figure 5A) and leaf mass ratio (LMR) (Figure 5B) of P.angulata L. plants. In relation to the leaf area ratio (LAR), which expresses the leaf area useful for photosynthesis (Benincasa, 2004), there was a significant difference between the growing periods. In this way, increases of $40.5 \%$ were observed in the period from December to February when compared to the cultivation from April to June (Figure 5A).
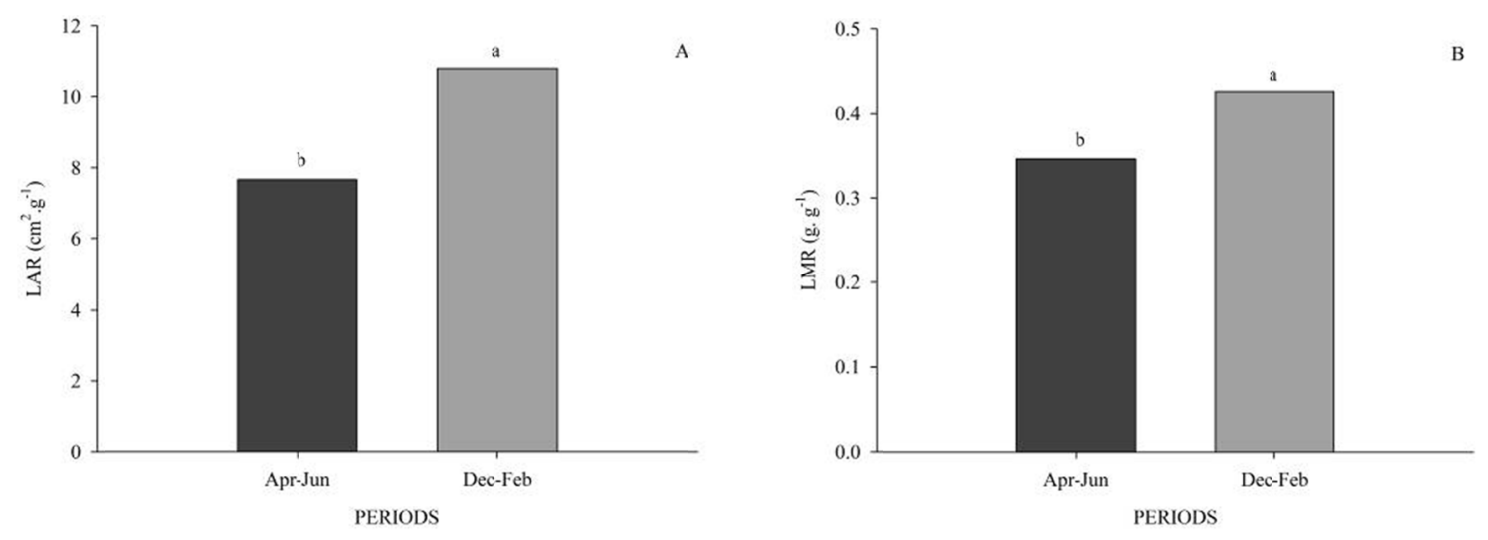

Figure 5. Leaf Area Ratio-LAR $\left(\mathrm{cm}^{2} \mathrm{~g}^{-1}\right)(\mathrm{A})$ and Leaf Mass Ratio-LMR $\left(\mathrm{g} \mathrm{g}^{-1}\right)(\mathrm{B})$ of Physalis angulata L. plants grown in the field in two periods (April to June 2016) and (December 2016 to February 2017). Averages followed by distinct letters differ statistically from one another by the $\mathrm{F}$ test at $5 \%$ probability

According to Benincasa (2004), LAR is the relation between the leaf area responsible for the interception of light energy and $\mathrm{CO}_{2}$ and the total dry mass. In cases of LAR reduction (28.8\%), as observed in the cultivation from April to June (Figure 5A), it indicates that the increase of the plant growth causes an overlap of the upper leaves on the lower leaves, thus reducing the useful leaf area, a fact that was observed when the plant was in the field.

According to Benincasa (2004), the leaf mass ratio (LMR), which represents the dry mass fraction produced by photosynthesis, was also influenced by the cultivation period, however, there was an increase in cultivation from December to February. Increases of $22.8 \%$ were observed in the LMR when compared to the cultivation from April to June (Figure 5B). According to Aumonde, Lopes, Moraes, Peil, and Pedó (2011) and C. Peixoto, Cruz, and M. Peixoto (2011), the LMR provides an estimate of the fraction of assimilates retained in the leaves and not exported to the other organs of the plant.

\subsection{Influence of the Cultivation Period on Total Flavonoids and Total Phenolics Concentration in Physalis angulata $L$.}

Considering that the bioactive contents were affected, according to the different periods, the cultivation from December to February provided an increase in total phenolics, total flavonoids and higher antioxidant activity in $P$. angulata $\mathrm{L}$.

Figure 6A shows that the total flavonoid content increased in all parts of the plant in the cultivation from December to February when compared to the period from April to June. Thus, increases of $40 \%, 38.46 \%$ and $173.6 \%$ were observed in leaves, stems and roots, respectively. The results suggest a way of adapting the species to the local abiotic factors, resulting in an increase in the concentration of these compounds. 

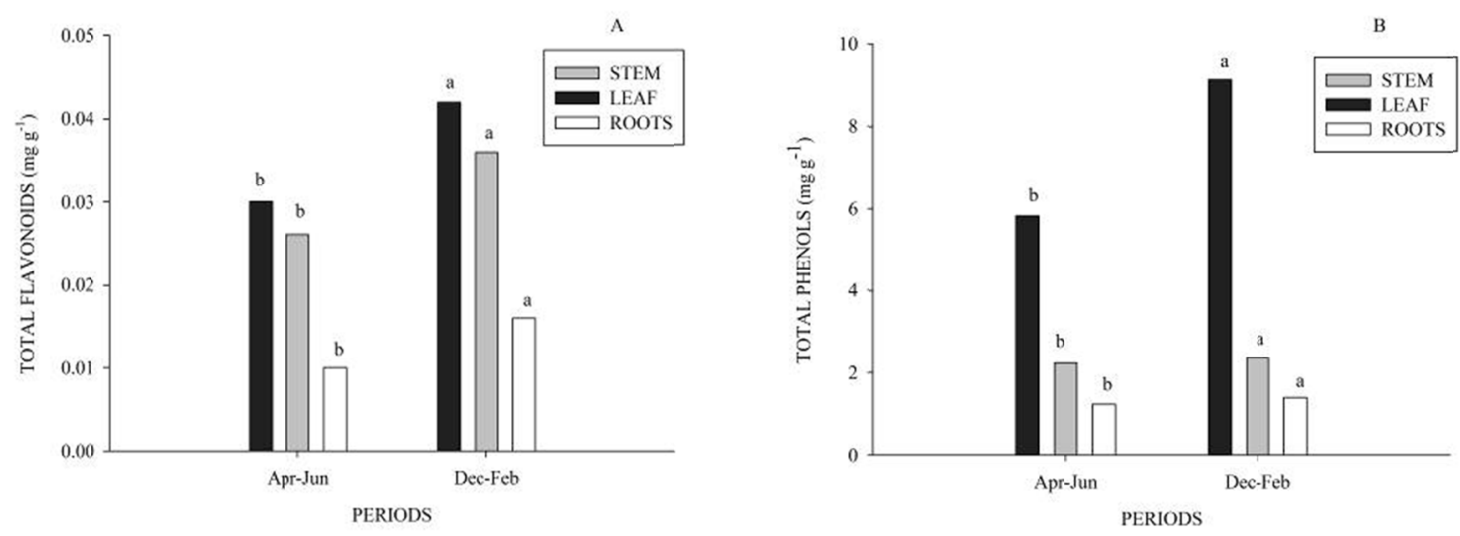

Figure 6. Total flavonoids $\left(\mathrm{mg} \mathrm{g}^{-1}\right)(\mathrm{A})$, in quercetin equivalent (QE) and total phenols $\left(\mathrm{mg} \mathrm{g}^{-1}\right)(\mathrm{B})$, in gallic acid equivalent (GAE) in leaves, stems and roots of Physalis angulata L. plants, cultivated in the field in two different periods (April to June 2016) and (December 2016 to February 2017). Averages followed by distinct letters differ statistically from one another by the $\mathrm{F}$ test at $5 \%$ probability

Observing Figure 6A, differences between the total flavonoid content in different parts of plants (leaves $>$ stems $>$ roots) are noted. Thus, in this study the highest concentration of flavonoids is located in the leaves of $P$. angulata. According to Simões et al. (2000), the flavonoids can present different concentrations depending on the vegetal part in which it is located. Probably, the aerial part because it is exposed to sunlight and presented the highest concentration of flavonoids in relation to the root, because according to Degáspari and Waszczynskyj (2004) the formation of flavonoids is accelerated by light. The period of December to February favored the increase of phenols and total flavonoids. In contrast to growth that was adversely affected. In slightly more adverse conditions, the plant invests in secondary metabolism, certainly trying to develop survival mechanisms.

According to Figure $6 \mathrm{~B}$, the period that presented the highest total phenolic content was the cultivation from December to February when compared to the cultivation from April to June. Thus, increases of $57 \%, 5.6 \%$, and $13 \%$ were observed in leaves, stems and roots, respectively.

Maisuthisakul, Suttajit and Pongsawatmanit (2007) studying some indigenous plants, classified the content of the phenolic compound in the extracts of herbs and vegetables in three ranges of values: Low $\leq 10 \mathrm{mg}$, medium from 10 to 20 and high $\geq 40 \mathrm{mg} \mathrm{GAE} \mathrm{g}^{-1}$ of dry mass of plant extract. The extract of leaves, stems and roots of $P$. angulata L., in this study, presented low levels of total phenols, in relation to the study of the mentioned author. Thus, the highest levels were found in leaves $\left(5.8 \mathrm{mg}\right.$ and $9.14 \mathrm{mg} \mathrm{GAE} \mathrm{g}^{-1}$ extract) from the first and second periods, respectively. According to Kusumaningtyas et al. (2015), the total phenolic content in extracts of $P$. angulata $\mathrm{L}$. depends on the type of extract, the polarity of the solvent used in the extraction, as well as the parts of the evaluated plant.

Kusumaningtyas et al. (2015), studying the potential of $P$. angulata as source of functional ingredient reported values in the leaves of $0.46 \mathrm{mg}$ of $\mathrm{GAE} \mathrm{g}^{-1}$ extract. This result is lower than that found in this study (5.8 $\mathrm{mg}$ and $9.14 \mathrm{mg} \mathrm{GAE}^{-1}$ extract) in the first and second periods, respectively (Figure 6B).

Jacobson et al. (2005), studying two medicinal species, Stryphnodendron adstringens and S. polyphyllum reported higher yields of total phenols in the rainy season of the year. These results differ from the study in question, in which the highest production of total phenols in Physalis was observed during the dry season, demonstrating the particularities of each plant species, which further validates the need for studies directed to each species and growing conditions Natural abiotic factors such as solar radiation, UV rays, time of year, periods of drought or rain, among other factors, may influence the metabolism and production of these compounds (Catherine \& Packer, 2003; Degáspari \& Waszczynskyj, 2004).

\subsection{Influence of the Cultivation Period on the Antioxidant Activity in Physalis angulata $\mathrm{L}$.}

It is probable that the climatic conditions, observed in the period of December to February, are the cause of the increase in the secondary metabolism of the $P$. angulata L. plants, as a way of adaptation to the adverse conditions of the place.

The values of the effective concentration $\left(\mathrm{EC}_{50}\right)$ found in the leaves of $P$. angulata $\mathrm{L}$., can be observed in Figure 7. 


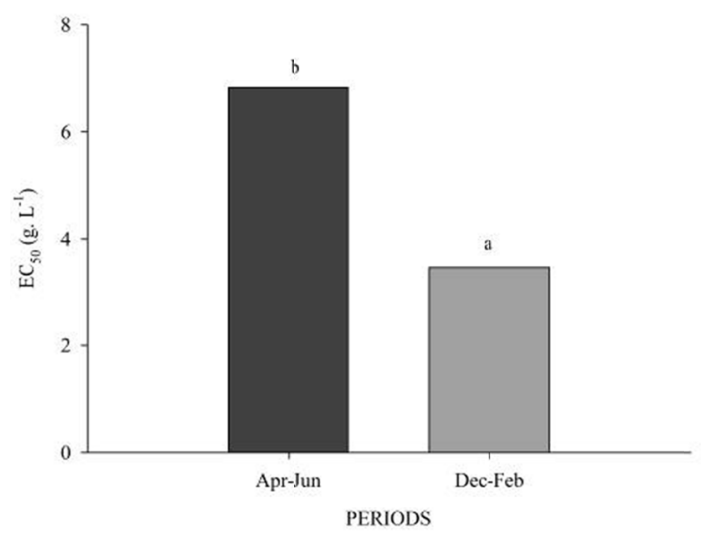

Figure 7. Effective concentration-EC ${ }_{50}\left(\mathrm{~g} \mathrm{~L}^{-1}\right)$ in leaves of Physalis angulata $\mathrm{L}$. plants, cultivated in the field in two different periods (April to June 2016) and (December 2016 to February 2017). Averages followed by distinct letters differ statistically from one another by the $\mathrm{F}$ test at $5 \%$ probability

The effective concentration $\left(\mathrm{EC}_{50}\right)$ of $P$. angulata $\mathrm{L}$. leaves, grown at different periods, ranged from $\mathrm{EC}_{50}=3.46$ $\mathrm{g} \mathrm{L}^{-1}$ in the cultivation from December to February, $\mathrm{EC}_{50}=6.83 \mathrm{~g} \mathrm{~L}^{-1}$ in the cultivation from April to June, as shown in Figure 7.

Leaves of P. angulata L., cultivated in the period from December to February presented lower value of $\mathrm{EC}_{50}$ and, consequently, greater antioxidant activity when compared to the cultivation from April to June. The effective concentration $\left(\mathrm{EC}_{50}\right)$ corresponds to the required concentration of the sample capable of inhibiting $50 \%$ of free radicals (Silva, Oliveira, Guedes, Bittencourt, \& Oliveira, 2014). Thus, the lower the value of $\mathrm{EC}_{50}$ is, the greater will be its antioxidant activity (Fabri, Nogueira, Dutra, Bouzada, \& Scio, 2011).

\section{Conclusion}

To obtain fruits, mainly in the region of the Bahia Reconcavo, $P$. angulata $\mathrm{L}$. should be cultivated from April to June. To obtain a higher concentration of bioactives such as total phenolics and total flavonoids the species should be cultivated from December to February.

\section{References}

Almeida, O. A. (1991). Informações meteorológicas do Centro Nacional de Pesquisa de Mandioca e Fruticultura Tropical. Cruz das Almas: EMBRAPA/CNPMF. Retrieved from https://www.embrapa.br/ busca-de-publicacoes/-/publicacao/636357/informacoes-meteorologicas-do-cnp---mandioca-e-fruticultura-tr opical

Aumonde, T. Z., Lopes, N. F., Moraes, D. M., Peil, R. M. N., \& Pedó, T. (2011). Análise de crescimento do híbrido de mini melancia Smile ${ }^{\circledR}$ enxertada e não enxertada. Interciencia, 36(9), 677-681. Retrieved from http://www.redalyc.org/articulo.oa?id=33921204007

Balasundram, N., Sundram, K., \& Samman, S. (2006). Phenolic compounds in plant and agri-industrial byproducts: Antioxidant activity, occurrence, and potential uses. Food Chemistry, 99(1), 191-203. https://doi.org/10.1016/j.foodchem.2005.07.042

Bastos, G. N., Silveira, A. J., Salgado, C. G., Picanço-Diniz, D. L., \& Nascimento, J. L. (2008). Physalis angulata extract exerts anti-inflammatory effects in rats by inhibiting different pathways. Journal of Ethnopharmacology, 118(2), 246-251. https://doi.org/10.1016/j.jep.2008.04.005

Benincasa, M. M. P. (2004). Análise de crescimento de plantas: Noções básicas. Jaboticabal: FUNEP.

Betemps, D. L., Fachinello, J. C., Lima, C. S. M., Galarça, S. P., \& Rufato, A. R. (2014). Época de semeadura, fenologia e crescimento de plantas de fisális no sul do Brasil. Revista Brasileira de Fruticultura, 36(1), 179-185. https://doi.org/10.1590/0100-2945-292/13

Carvalho, A. V., Mattietto, R. A., Rios, A. O., \& Moresco, K. S. (2014). Mudanças nos compostos bioativos e atividade antioxidante de pimentas da região amazônica. Pesquisa Agropecuária Tropical, 44(4), 399-408. https://doi.org/10.1590/S1983-40632014000400004

Catherine, A. R., \& Packer, L. (2003). Flavonoids in health and disease. New York: Basel. 
Degáspari, C. H., \& Waszczynskyj, N. (2004). Propriedades antioxidantes de compostos fenólicos. Visão Acadêmica, 5(1), 33-40. https://doi.org/10.5380/acd.v5i1.540

Empresa Brasileira de Pesquisa Agropecuária (EMBRAPA). (2013). Sistema Brasileiro de Classificação de Solos. Brasília: EMBRAPA.

Fabri, R. L., Nogueira, M. S., Dutra, L. B., Bouzada, M. L. M., \& Scio, E. (2011). Potencial antioxidante e antimicrobiano de espécies da família Asteraceae. Revista Brasileira de Plantas Medicinais, 13(2), 183-189. https://doi.org/10.1590/S1516-05722011000200009

Ferreira, D. F. (2011). Sisvar: A computer statistical analysis system. Ciência \& Agrotecnologia, 35(6), 1039-1042. https://doi.org/10.1590/S1413-70542011000600001

Guimarães, E. T., Lima, M. S., Santos, L. A., Ribeiro, I. M., Tomassini, T. B. C., Santos, R. R., ... Soares, M. B. P. (2009). Activity of physalins purified from Physalis angulata in vitro and in vivo models of cutaneous leishmaniasis. Journal of Antimicrobial Chemotherapy, 64(1), 84-87. https://doi.org/10.1093/jac/dkp170

Instituto Nacional de Meteorologia (INMET). (2017). Estações automáticas. Retrieved March 4, 2017, from http://www.inmet.gov.br

Ismail, N., \& Alam, M. (2001). A novel cytotoxic flavonoid glycoside from Physalis angulata. Fitoterapia, 72(6), 676-679. https://doi.org/10.1016/S0367-326X(01)00281-7

Jacobson, T. K. B., Garcia, J., Santos, S. C., Duarte, J. B., Farias, J. G., \& Kliemann, H. J. (2005). Influência de fatores edáficos na produção de fenóis totais e taninos de duas espécies de barbatimão (Stryphnodendron sp.). Pesquisa Agropecuária Tropical, 35(3), 163-169. https://doi.org/10.5216/pat.v35i3.2218

Kusumaningtyas, R. W., Laily, N., \& Limandha, P. (2015). Potential of Ciplukan (Physalis angulata L.) as Source of Functional Ingredient. Procedia Chemistry, 14, 367-372. https://doi.org/10.1016/j.proche. 2015.03.050

Lee, H. Z., Liu, W. Z., Hsieh, W. T., Tang, F. Y., Chung, J. G., \& Leung, H. W. C. (2009). Oxidative stress involvement in Physalis angulata-induced apoptosis in human oral cancer cells. Food and Chemical Toxicology, 47(3), 561-570. https://doi.org/10.1016/j.fct.2008.12.013

Lima, C. S. M., Gonçalves, M. A., Tomaz, Z. F. P., Rufato, A. R., \& Fachinello, J. C. (2010). Sistemas de tutoramento e épocas de transplante de Physalis. Ciência Rural, 40(12), 2472-2479. https://doi.org/10.1590/ S0103-84782010001200006

Maisuthisakul, P., Suttajit, M., \& Pongsawatmanit, R. (2007). Assessment of phenolic content and free radical-scavenging capacity of some Thai indigenous plants. Food Chemistry, 100(4), 1409-1418. https://doi.org/10.1016/j.foodchem.2005.11.032

Marques, G. S., Monteiro, R. P. M., Leão, W. F., Lyra, M. A. M., Peixoto, M. S., Rolim-Neto, P. J., ... Soares, L. A. L. (2012). Avaliação de procedimentos para quantificação espectrofotométrica de flavonoides totais em folhas de Bauhinia forficata LINK. Química Nova, 35(3), 517-522. https://doi.org/10.1590/S0100-404220 12000300014

Martinazzo, E. G., Perboni, A. T., Posso, D. A., Aumonde, T. Z., \& Bacarin, M. A. (2015). Análise de crescimento e partição de assimilados em plantas de tomateiro cv. Micro-Tom submetidas ao nitrogênio e piraclostrobina. Semina: Ciências Agrárias, 36(5), 3001-3012. https://doi.org/10.5433/1679-0359.2015 v36n5p3001-3012

Matos, F. J. A. (2000). Plantas medicinais: Guia de seleção e emprego de plantas usadas em fitoterapia no Nordeste do Brasil (2nd ed.). Fortaleza, CE: UFC.

Peixoto, C. P., Cruz, T. V., \& Peixoto, M. F. S. P. (2011). Análise quantitativa do crescimento de plantas: Conceitos e Prática. Enciclopédia Biosfera, 7(13), 51-76. Retrieved from http://www.conhecer.org.br/ enciclop/2011b/ciencias\%20agrarias/analise\%20quantitativa.pdf

Petry R. D., Souza, K. C. B., \& Ortega, G. G. (1998). Doseamento do teor de flavonóides totais em extratos hidroalcóolicos de Passiflora alata Cryander (maracujá). Revista Brasileira de Farmácia, 79, 7-10. Retrieved from https://www.lume.ufrgs.br/bitstream/handle/10183/103152/000264226.pdf?sequence=1

Reis, L. S., Azevedo, C. A. V., Albuquerque, A. W., \& Junior, J. S. (2013). Índice de área foliar e produtividade do tomate sob condições de ambiente protegido. Revista Brasileira de Engenharia Agrícola e Ambiental, 17(4), 386-391. https://doi.org/10.1590/S1415-43662013000400005 
Rufato, A. R., Rufato, L., Lima, C. S. M., \& Muniz, J. (2013). A cultura da Physalis. Série fruticultura-pequenas frutas, CAV/UDESC. Retrieved from https://www.alice.cnptia.embrapa.br/alice/bitstream/doc/995307/1/ RUFATOCulturaPhysalis.pdf

Rufino, M. S. M., Alves, R. E., Brito, E. S., Morais, S. M., Sampaio, C. G., Pérez-Jiménez, J., \& Saura-Calixto, F. D. (2007). Metodologia Científica: Determinação da Atividade Antioxidante Total em Frutas pela Captura do Radical Livre DPPH. Comunicado Técnico on line 127. Fortaleza, CE: Fortaleza: Embrapa Agroindústria Tropical. Retrieved from http://www.infoteca.cnptia.embrapa.br/bitstream/doc/426953/1/ Cot127.pdf

Silva, J. A., Oliveira, F. F., Guedes, E. S., Bittencourt, M. A. L., \& Oliveira, R. A. (2014). Atividade antioxidante de Piper arboreum, Piper dilatatum e Piper divaricatum. Revista Brasileira de Plantas Medicinais, 16(3), 700-706. https://doi.org/10.1590/1983-084X/13_097

Simões, C. M. O., Schenquel, E. P., Gosmann, G., Pallazo-de-Mello, J. C., Mentz, L. A., \& Petrovick, P. R. (2000). Farmacognosia da planta ao medicamento (2nd ed.). Porto Alegre, Florianópolis: UFRGS/UFSC.

Slinkard, K., \& Singleton, V. (1977). Total phenol analysis: Automation and comparison with manual methods. American Journal of Enology and Viticulture, 28(1), 49-55. Retrieved from http://www.ajevonline.org/ content/28/1/49

Souza, C. L. M. (2015). Armazenamento de sementes e caracterização morfofisiológica de espécies do gênero Physalis (Tese de Doutorado, Universidade Estadual de Feira de Santana, Feira de Santana, BA, Brasil). Retrieved from http://rgv.web2207.uni5.net/dissertacoes/79.pdf

Souza, M. O., Pelacani, C. R., Willems, L. A. J., Castro, R. D., Hilhorst, H. W. M., \& Ligterink, W. (2016). Effect of osmopriming on germination and initial growth of Physalis angulata $\mathrm{L}$. under salt stress and on expression of associated genes. Anais da Academia Brasileira de Ciências, 88(1) 503-516. https://doi.org/ 10.1590/0001-3765201620150043

Souza, M. O., Souza, C. L. M., Barroso, N. S., \& Pelacani, C. R. (2014). Preconditioning of Physalis angulata L. to maintain the viability of seeds. Acta Amazonica, 44(1), 153-156. https://doi.org/10.1590/S0044-5967 2014000100015

Stehmann, J. R., Mentz, L. A., Agra, M. F., Vignoli-Silva, M., Giacomin, L., \& Rodrigues, I. M. C. (2015). Solanaceae in Lista de Espécies da Flora do Brasil. Jardim Botânico do Rio de Janeiro. Retrieved from http://floradobrasil.jbrj.gov.br/jabot/floradobrasil/FB14697

Sun, L., Liu, J., Liu, P., Yu, Y., Ma, L., \& Hu, L. (2011). Immunosuppression effect of Withangulatin A from Physalis angulata via heme oxygenase 1-dependent pathways. Process Biochemistry, 46(2), 482-488. https://doi.org/10.1016/j.procbio.2010.09.022

Taiz, L., \& Zeiger, E. (2013). Fisiologia vegetal. Porto Alegre: Artmed.

Tomassini, T. C. B., Barbi, N. S., Ribeiro, I. M., \& Xavier, D. C. D. (2000). Gênero Physalis-Uma revisão sobre vitaesteróides. Química Nova, 23(1), 47-57. https://doi.org/10.1590/S0100-40422000000100011

Yu, Y., Sun, L., Ma, L., Li, J., Hu, L., \& Liu, J. (2010). Investigation of the immunosuppressive activity of Physalin $\mathrm{H}$ on $\mathrm{T}$ lymphocytes. International Immunopharmacology, 10(3), 290-297. https://doi.org/ 10.1016/j.intimp.2009.11.013

Zuffo, A. M., Zuffo Júnior, J. M., Silva, L. M. A., Silva, R. L., \& Menezes, K. O. (2016). Análise de crescimento em cultivares de alface nas condições do sul do Piauí. Revista Ceres, 63(2), 145-153. https://doi.org/ $10.1590 / 0034-737 X 201663020005$

\section{Copyrights}

Copyright for this article is retained by the author(s), with first publication rights granted to the journal.

This is an open-access article distributed under the terms and conditions of the Creative Commons Attribution license (http://creativecommons.org/licenses/by/4.0/). 